\title{
カムチャツカ日露共同標識調査特集にあたって
}

\author{
尾崎清明*

\section{Special Issue for the International Japan-Russia Bird Banding Expedition on Kamchatka Peninsula}

Kiyoaki OZAKI*

日本に冬季渡ってくる渡り鳥の主要な繁殖地がロシアの極東地域であることは, その地理的状況か ら十分に推測される。しかし, 実際にこの地域と日本を結びつける鳥類の標識回収記録の大部分が力 モ類であり，日本で標識放鳥数が多いスズメ目に関しては，ロシアとの回収記録がこれまでほとんど 得られていなかった．これはロシア極東地域では狩猟が盛んなため対象となるカモ類は回収されるが, スズメ目鳥類の標識調査が極めてわずかであることに起因していると思われる，それを裏付ける資料 としては, 近年両国の研究者によって活発に行なわれるようになったガン類やユリカモメのカラーマー キング調査によって，それまで不明であったこれらの種の両国間の移動実態が急速に明らかになって きていることがあげられる。こうした現状を踏まえると, この地域で実際に標識調査を実施すること は，両国間の標識回収記録を増加させるもっとも有効な手段であろうと考えられた．また調查を通し て鳥類の生息や渡り状況を把握することが可能となり, さらに現地の研究者と共同で行なうことによっ て今後の調查者の育成に役立つことも期待された.

1996年 9 月の大会で, 日本鳥類標識協会の海外共同調査の第 1 弾として, カムチャツカ半島におけ る鳥類標識調査の企画が採択された。 カムチャツカが選ばれたのは, 渡り鳥で日本との関連が深いと 推測されたことは勿論であるが，すでにガン類やユリカモメなどの調査で日本の研究者との交流があ るロシア・科学アカデミー・カムチャツカ生態学研究所の鳥類研究者であるゲラシモフ親子の存在が 大きく関わっている．父親のニコライ・ゲラシモフ博士は鳥類の渡り全般への研究をしており，近年 はシジュウカラガンの再導入計画を精力的に主導している. 息子のユーリ・ゲラシモフ博士は, ガン カモ類，シギチドリ類とともにスズメ目の渡りについてもすでに基礎的な研究を進めていたところで あった．したがって日本鳥類標識協会との共同調査に快諾してくれた. また両博士の所属機関である, カムチャツカ生態学研究所からも共同調査の承諾を得ることができた.

調査にかかる経費については, 初年度の1997年は日本鳥類標識協会の海外共同調査として組んだ予 算から執行したが, 翌1998年の調査からはプロ・ナトゥーラ・ファンドの海外助成を得ることができ た. 同助成金はユーリ・ゲラシモフ氏が申請者となり，「カムチャツカ半島と日本の間の鳥類の渡り解 明, 一保護のための基礎的研究一」と題して, 尾崎が推薦人となって 3 年間継続（1997年～1999年度） して受けることができた。また日本鳥類標識協会からも海外共同調査の予算は継続され，これは主に 日本から参加する代表者の渡航費や共同経費に当てられた。その他の日本側からの参加者は, 渡航費 やホテルなどでの宿泊費, 食費などを自己負担した.

本格的な共同調査に先立って, 初年度の1997年には梶田 学さんが予備調査を実施した。単独の旅行 
にもかかわらず，若さと人当たりの良さでロシア側の関係者と緊密な関係を構築し，調查方法などに 関してもその後の調査に役立つ有益な情報を収集した。翌1998年は須川 恒さんを団長として，7名が 参加した。すでにユリカモメの調査でゲラシモフ親子と親しかった須川さんは，もちまえの几帳面さ を発揮して，鳥類リストやロシア語単語帳などを準備し，最も重要な標識記録のフォーマットを整備 するなど貢献した。

1999年は千葉 晃さんを団長とし，5名が参加した。新潟でメボソムシクイの分類や渡りに興味を 持っていた千葉さんは，日露の比較を中心に大変興味深い結果をまとめた．最終の2000年は私を含め て 7 名が参加したが, 深井宣男さんは現地調査でも中心的に活躍し, その後この報告書の取りまとめ も引き受けた。またこの年の調査に参加した植田潤さんがこの特集の表紙絵を担当した。皆さんのお かげで充実した内容の報告となった.

カムチャツカ共同調査特集の構成は，まず 4 年間の結果の全般についてとりまとめと解析をおこな い, その上でいくつかの中心的な課題を各担当者が論文の形式で報じている．各年度の詳細は「紀行 文」として年度毎にとりまとめた。これらはすでに速報としてバンダーニュースで紹介したものに加 筆したものである.

共同調査で得られた成果で特筆すべきことのひとつは，カムチャツカと日本の間の回収記録の増加

表 1。カムチャツカ半島と日本の間の回収記録（1962年～2008年）.

Table 1. Recoveries between Kamchatka and Japan (1962 to 2008).

\begin{tabular}{|c|c|c|c|c|c|}
\hline & & \multicolumn{2}{|c|}{ Japan $\rightarrow$ Kamchatka } & \multicolumn{2}{|c|}{ Kamchatka $\rightarrow$ Japan } \\
\hline & & $1962-2008$ & $1997-2008 *$ & $1962-2008$ & 1997-2008* \\
\hline ヒシクイ & Anser fabalis & & & 6 & \\
\hline マガモ & Anas platyrhynchos & 7 & & 1 & \\
\hline コガモ & Anas crecca & 36 & & & \\
\hline ヨシガモ & Anas falcata & 16 & & & \\
\hline ヒドリガモ & Anas penelope & 96 & 3 & & \\
\hline オナガガモ & Anas acuta & 572 & 57 & & \\
\hline ハシビロガモ & Anas clypeata & 8 & & & \\
\hline ホシハジロ & Aythya ferina & 1 & 1 & & \\
\hline キンクロハジロ & Aythya fuligula & 3 & & & \\
\hline スズガモ & Aythya marila & 1 & & & \\
\hline キョウジョシギ & Arenaria interpres & 1 & & & \\
\hline ハマシギ & Calidris alpina & 1 & & & \\
\hline トウネン ～～～～～～ & Calidris ruficollis & & & 1 & \\
\hline チュウシャクシギ & Numenius phaeopus & 1 & & & \\
\hline ユリカモメ & Larus ridibundus & 3 & & 24 & 2 \\
\hline ハクセキレイ & Motacilla alba & 2 & & & \\
\hline ノゴマ & Lusciana calliope & & & 1 & \\
\hline キタヤナギムシクイ & Phylloscopus trochilus & & & 1 & \\
\hline カシラダカ & Emberiza rustica & 1 & & 1 & \\
\hline \multirow[t]{2}{*}{ オオジュリン } & Emberiza schoeniclus & 11 & 8 & 28 & 28 \\
\hline & & 760 & 69 & 63 & 30 \\
\hline
\end{tabular}

本表にはガン類やユリカモメで多数得られているカラーマーキング個体の観察による回収例は含んでいない.

* 太字は本共同調査以降の回収記録数 
である. 1962年から2008年までの間で, カムチャツカと日本との間での標識調查による回収例は20種 823例がある（表 1 ）。このうちオオジュリンでは, 共同調査以前は日本で放鳥しカムチャツカで回収 された 3 例のみであったが, 共同調査以降は日本で放鳥しカムチャツカで回収された 8 例と, カムチャ ツカで放鳥し日本で回収された28例が加わるといった顕著な増加が見られた。

この特集が日本鳥類標識協会の会員をはじめ, 多くの方に読まれることによって, 同地域の鳥類に 対する理解を深め, さらには今後の日本鳥類標識協会の共同調査に役立つことを期待している.

最後に, このカムチャツカ調査に参加された協会員とロシア側のメンバー, それらを支えて下さっ た日本鳥類標識協会とプロ・ナトゥーラ・ファンドに心から感謝する.

尾崎清明* ozaki@yamashina.or.jp

T270-1145 千葉県我孫子市高野山115 山階鳥類研究所保全研究室

Kiyoaki Ozaki* ozaki@yamashina.or.jp

Yamashina Institute for Ornithology, Division of Avian Conservation 115 Konoyama Abiko, Chiba 270-1145, Japan 